\title{
PEMFC Optimization Strategy with Auxiliary Power Source in Fuel Cell Hybrid Vehicle
}

\author{
Tinton Dwi Atmaja ${ }^{1}$ and $\mathrm{Amin}^{2}$
}

\begin{abstract}
Fuel Cell Hybrid Vehicle (FCHV). This paper proposes some strategies to optimize the performance of Polymer Electrolyte Membrane Fuel Cell (PEMFC) implanted with auxiliary power source to construct a proper FCHV hybridization. The strategies consist of the most updated optimization method determined from three point of view i.e. Energy Storage System (ESS), hybridization topology and control system analysis. The goal of these strategies is to achieve an optimum hybridization with long lifetime, low cost, high efficiency, and hydrogen consumption rate improvement. The energy storage system strategy considers battery, supercapacitor, and high-speed flywheel as the most promising alternative auxiliary power source. The hybridization topology strategy analyzes the using of multiple storage devices injected with electronic components to bear a higher fuel economy and cost saving. The control system strategy employs nonlinear control system to optimize the ripple factor of the voltage and the current and using the AOC-EMS system to improve the hydrogen consumption rate. ECMS and BERS strategy based on Time-Triggered Controller Area Network (TTCAN) also promoted to optimize hydrogen consumption rate from recovered kinetic energy while in braking regeneration mode.
\end{abstract}

\section{Keywords—PEMFC, optimization strategy, FCHV, ESS, control system, hybridization topology}

Abstrak-Salah satu implementasi sel bahan bakar saat ini adalah berfungsi sebagai sumber daya utama pada kendaraan hibrida berbasis sel bahan bakar (FCHV). Makalah ini mengusulkan beberapa strategi untuk mengoptimalkan kinerja sel bahan bakar jenis polymer electrolyte membrane (PEMFC) yang digabungkan dengan sumber energi lainnya untuk membangun sebuah hibridisasi FCHV yang tepat. Strategi terdiri dari metode optimasi terkini dilihat dari tiga sudut pandang yaitu sistem penyimpanan energi (ESS), topologi hibridisasi dan analisis sistem kontrol. Tujuan dari strategi ini adalah untuk mencapai hibridisasi optimal dengan masa pakai lama, biaya rendah, efisiensi tinggi, dan perbaikan tingkat konsumsi hidrogen. Strategi sistem penyimpanan energi menggunakan baterai, super dan roda gila kecepatan tinggi (high-speed flywheel) sebagai sumber listrik alternatif yang paling menjanjikan. Strategi topologi hibridisasi menganalisis penggunaan beberapa perangkat penyimpanan energi digabungkan dengan komponen elektronik untuk menghasilkan bahan bakar yang ekonomis dan hemat biaya. Strategi sistem kontrol menggunakan sistem kontrol nonlinier untuk mengoptimalkan faktor riak tegangan dan arus dan menggunakan sistem AOC-EMS untuk meningkatkan efisiensi hidrogen. Strategi ECMS dan BERS berdasarkan Time-Triggered Controller Area Network (TTCAN) juga dipromosikan untuk mengoptimalkan tingkat konsumsi hidrogen dari pemulihan energi kinetik ketika terjadi pengereman.

Kata Kunci-PEMFC, strategi optimalisasi, FCHV, ESS, sistem kendali, topologi hibrid

\section{INTRODUCTION}

$\mathrm{R}$ enewable energy, energy conservation and sustainable transport become global concern along with the issues of depletion of fossil fuel and global warming. Most petroleum is used by various ground vehicles. The U.S. Energy Information Administration stated that the United States consumed 18.7 million barrels of petroleum per day in the first half of 2009 . And it is believed that the global number of vehicles will increase from 700 million to 2.5 billion in the next 50 years. When it is announced that current global petroleum resources could be used up to within 50 years if they are consumed at present consumption rates, methods of improving vehicular fuel economy have gained worldwide attention [1-2].

Many research about sustainable transport like Electric Vehicle (EV), Hybrid Electric Vehicle (HEV), Fuel Cell

Tinton Dwi Atmaja is with Mechatonics Division, Research Centre for Electrical Power and Mechatronics, LIPI, Indonesia, E-mail: tinton_dwi@yahoo.com.

Amin is with School of Electrical Engineering and Informatics, Institut Teknologi Bandung, Bandung 40132, Indonesia, E-mail: amin_hwi@yahoo.co.id.
Hybrid Vehicle (FCHV), and Plug-In Hybrid Electric Vehicle (PHEV) have proven to be an effective solution for current energy and environment concerns. With continuous research of power electronics and EnergyTorage System (ESS), electric drive trains totally or partially replace Internal Combustion Engine (ICE) in today vehicles. Thus, researchers are investigating hybrid ESSs with large capacity, fast charging/discharging, long lifetime, and low cost. For the purpose of making hybrid vehicles competitive with conventional vehicles in the market, additional research efforts should be focused on decreasing cost and improving efficiency. Other efforts is increasing electric driving range of future advanced vehicles by introducing transformational ESSs capable of improving fuel consumption [2].

One of the sustainable transports, FCHVs, is using two energy sources to support their electric powertrain. The primary power source is PEMFC and the second energy source is the energy buffer (battery or supercapacitor) to be hybridized to the fuel cell system [3]. The Polymer Electrolyte Membrane Fuel Cell (PEMFC) stack represents one of the most used solutions as main energy source in Energy Generation System (EGS) and vehicle applications because of its small size, the ease of 
construction, a fast start-up and low operating temperature. Most drivers would not accept more than 15-20 min charging times on long distance travel for EVs so that the refueled time is one FC vehicle advantage when it can refuel in 3-5 minutes [4-5].

To optimize the performance of this PEMFC while hybridized with other power source, this paper proposes some strategies determined form several points of view. The first strategy absolutely about choosing method which energy storage system is the most optimum to be hybridized with PEMFC. The second strategy is about constructing the best topology for higher fuel economy. The last strategy is concern about applying control systems to create the optimum parameter in the Hybrid Power Source (HPS) and to improve the hydrogen consumption rate.

\section{METHOD}

On this method will be presented several strategies consist of the most updated optimization strategy determined from three point of view i.e. Energy Storage System (ESS), hybridization topology and control system analysis.

\section{A. ESS Strategy}

Since most FC Electric vehicles have one Energy Storage System (ESS) there are needs to choose which energy storage system (energy buffer) to be the best hybridization. There are two storage system commonly used to assist PEMFC in today research of electric vehicle i.e. Battery and Supercapacitor (or ultracapacitor), plus one emerging technology called high-speed flywheel [6-7].

\section{Battery}

Battery is still the most favorite energy storage. They adopted in widely due to their characteristics in terms of high energy density, compact size, and reliability. Most common type of used battery is [2]:

- Lead-Acid (Pb-A) Batteries

- Nickel-Metal Hydride (NiMH) Batteries

- Lithium-Ion (Li-Ion) Batteries

- Nickel-Zinc (Ni-Zn) Batteries

- Nickel-Cadmium (Ni-Cd) Batteries

Figure 1 presented structure of hybridization between PEMFC and batteries [6]. The battery was connected to the DC bus usually without converter but the FC need one DC-DC converter. To be noted that battery cannot be charged or discharged at high current and high-current charges discharges from battery will reduce its lifetime.

From those five types of commonly used battery, previous research stated that lithium-ion battery as the auxiliary power in FCHV can reduced fuel consumption to $2 / 3$ of that without battery [8]. It is one quantitative proof that lithium-ion battery is an excellent auxiliary power source to be hybridized with PEMFC. Somehow, the absence of a DC-DC converter connected to the fuel cell or the battery makes the system easier, lighter and cheaper previous analysis also stated that by adjusting the battery cell operating pressure, can result an active power sharing realized in a fuel cell/battery passive hybrid power source [9]. This allows for sustaining the battery state of charge and to fulfill the power demand of an automotive powertrain.

\section{Supercapacitor}

Supercapacitor or ultracapacitor stores energy by physically separating positive and negative charges on two parallel plates divided by an insulator. Since there are no chemical variations on the electrodes, therefore, supercapacitor has a long cycle life but low energy density [2]. There are five supercapacitor technologies in development: carbon/metal fiber composites, foamed carbon, a carbon particulate with a binder, doped conducting polymer films on a carbon cloth, and mixed metal oxide coatings on a metal foil. Higher energy density can be achieved with a carbon composite electrode using an organic electrolyte rather than a carbon/metal fiber composite electrode with an aqueous electrolyte [10].

Figure 2 presented the hybridization structure between PEMFC and supercapacitor [6]. There appear two DCDC converters must use before the junction on the DC bus. One of the DC-DC converters is bidirectional converter. To be noted that supercapacitor can be charged or discharged at high current.

Using monte-carlo approach and modified genetic algorithm using penalties method, it allows fast computation time and avoids slackening effect. Previous research also presented the results of the multiobjectives regarding the volume, the cost, the weight of the car. And finally, these objectives seem to be strongly linked together, and the number of Fuel Cell seems to be a key factor in the design [11-12].

In comparison between FC / battery vs FC / supercapacitor, FC / Supercapacitor has an advantage than FC / battery especially in lightweight vehicle. Although the fuel consumption rate is not significantly different, but FC / Supercapacitor is better in other issues e.g. bus voltage, cost and packaging consideration [13].

\section{High-Speed Flywheel}

A high-speed flywheel is one viable energy storage systems especially for electric vehicle. It usually store energy for power systems when it's coupled to an electric machine. Stored energy depends on the moment of inertia of the rotor and the square of the rotational velocity of the flywheel [14]. Figure 3 show flywheel functioning as an ESS integrated into a powertrain [7].

In Figure 3a, known as electrical integration, the flywheel is connected to an electric motor/generator via a fixed ratio gearbox and then is connected to the electric bus. This method allows for more flexibility in packaging the flywheel system in the vehicle. In Figure $3 \mathrm{~b}$, known as mechanical integration, the flywheel is connected to a Continuously Variable Transmission (CVT) which interfaces with the driveshaft via a clutch. Integrating the flywheel via the CVT is more efficient, since the flywheel does not receive power that has been subjected to motor/generator, gearbox, and wheel.

On the New European Driving Cycle (NEDC), the fuel economy of the most fuel efficient flywheel (standard size) was $4 \%$ and $6 \%$ lower than the most fuel efficient ultracapacitor and battery arrays respectively. The most fuel efficient flywheel costs approximately the same as the most fuel efficient battery array, and is potentially up to 2.8 times less expensive than the most fuel efficient ultracapacitor array. 


\section{B. Topology Strategy}

These proposed topologies are designed to hybridized FC and auxiliary power sources [15-16]. The promising topology of FC/battery/Ultracapacitor is believed to be optimized by analytically inserting a tool (diode) onto the topology. An analytical optimization method is developed for the general battery-diode-ultracapacitor circuit used in the novel topology.

Figure 4 shows FC-B-UC topologies. Figure 1(a) shows the most promising FC-B-UC topology from the literature [17-19] which is further labeled as Topology 1. Figure 1(b) shows the novel FC-B-UC powertrain topology presented in [18] which is labeled Topology 2, Option 1, and Figure 1(c) shows the proposed novel FCB-UC powertrain topology which features an antiparallel switch across the diode which is further labeled as Topology 2, Option 2.

Parametric study conducted by Jennifer Bauman et al of those three topologies shown in Figure 5 [16]. The parametric study shows that the topology 2 scores average fuel economy increased for 0.226 mpgge or $5.1 \%$ higher than topology 1 . The average cost savings between topology 1 and topology 2 (including the battery, ultracapacitor, low-power DC-DC converter, diode, and switch) shown is $\$ 1675$, or $11.14 \%$. Topology 2 definitely has a lower mass than Topology 1 since Topology 2 has no high-power DC-DC converter required for the battery.

\section{Equipment Installation}

Many works have been done to develop the utilization of FCHV from low to long range vehicle. Nowadays, FC power is in the range of $0.5-\mathrm{kW}$ to $2-\mathrm{MW}$ with following classification [20].

- $0.5-\mathrm{kW}$ to $2-\mathrm{kW}$ for unmanned aircrafts and 40 $\mathrm{kW}$ to $700-\mathrm{kW}$ for manned aircrafts;

- $50-\mathrm{kW}$ to $100-\mathrm{kW}$ for urban cars;

- 100-kW to 200-kW for buses and light tram;

- 600-kW to 1-MW for tramways and locomotives;

- $480-\mathrm{kW}$ to 2-MW for distributed generation systems (grid parallel connection).

Relatively short life cycle of most commonly used PEMFC calls a significant barrier to mobile application. Currently, the lifetime target requires PEM fuel cells to achieve $5000 \mathrm{~h}$ for mobile and 40,000 h for stationary applications [21]. A longer life span should be achieved using auxiliary power source. According to limited space available in every type of FCHV, the structure must be designed using the most appropriate auxiliary power source. The calculation must observe the acquired mass and the required volume of the whole system.

Figure 6 shows the vehicle mass as a function of the vehicle range (the power trains of all vehicles are adjusted to provide a zero to $97 \mathrm{~km} / \mathrm{hr}$ (60 mph) acceleration time of $10 \mathrm{~s}$ ) [22]. The compared batteries are $\mathrm{Pb}-\mathrm{A}, \mathrm{NiMH}$, and Li-ion batteries. The figure shows that extra mass is needed in accordance with the range of the vehicle. Fuel cell can provide electricity five times more energy per unit mass than current $\mathrm{NiMH}$, and two times more that advanced Lithium-ion. As the result among the batteries, $\mathrm{Pb}-\mathrm{A}$ has the heaviest mass, $\mathrm{NiMH}$ followed in the medium mass, and Li-Ion is the lightest. The nonlinear growth in mass with the vehicle range is the result of compounding every extra mass required for structural mass, heavier brake, and a larger traction.

Figure 7 shows the ESS volume in a function of the vehicle range (the fuel cell system is included in the storage volume since the hydrogen tank plus the fuel cell system is required to match the function of the battery bank) [22]. Since $\mathrm{Pb}-\mathrm{A}$ have extra volume compared with $\mathrm{NiMH}$ and $\mathrm{NiMH}$ is bigger that Li-Ion in the same power range unit, then it simply concluded that Li-Ion can achieve a longer range than the previous two. The longer the vehicle range, the more space is required.

The installation of the ESS usually near the power train stack but it will vary depending on the type of the vehicle. The vehicle type will depend on the overall weight and the necessary mileage. Fig 8 shows the common configuration of modified PEMFC-Battery light hybrid vehicle [23].

\section{Control System Strategy}

From the point of view of control system, there are some proven strategies to be implemented in PEMFC for FC hybrid vehicle.

\section{Nonlinear Control System}

Two sources, voltage source and current source, were controlled using nonlinear control system to improve the performance of the fuel cell implanted to HPS.

a) Voltage Control : A nonlinear voltage-mode control for fuel cell/battery/ultracapacitor HPS that improves the performance and durability of fuel cell [24]. The bi-buck HPS topology was designed to mitigate LF current ripple on the HPS output node by injection of an anti-ripple current on this point where the Controlled Voltage Source (CVS) and the Controlled Current Source (CCS) are connected as nonlinear load. Nonlinear CVS controller is designed to assure good performances in both frequency and time domain. The nonlinear voltage CVS controller performs an output voltage ripple factor up to $4 \%$ and an EMI reduction in the operation of bibuck HPS. This is done by spreading the power spectrum in the HF band using a nonlinear control law. The spreading in the HF band of the LF Ripple that remains after compensation by injection of the anti-ripple current leads to an increasing of the life cycle as well.

b) Current Control : A nonlinear current-mode control for the fuel cell/battery/ultracapacitor HPS that improves the ripple factor of the fuel cell current [25]. The nonlinear current control is designed to generate an antiripple via buck current controlled source in order to mitigate the inverter current ripple. The results successfully show that nonlinear current-mode control determines in the low frequency-domain better performances than other current-mode control techniques, such as the hysteretic current-mode controller or the peak current-mode controller. The CCS controller using nonlinear current-mode provides good performances that are independently by the load power level. The obtained current ripple factor in practice is expected to be up to $3 \%$.

\section{ECMS and BERS}

Equivalent Consumption Minimization Strategy (ECMS) and Braking Energy Regeneration Strategy (BERS) are control strategies based on Time-Triggered Controller Area Network (TTCAN) aiming at promoting the fuel economy [26]. 
a) ECMS: The concept of equivalent fuel consumption strategy was proposed by Paganelli et al. for the development of an instantaneous optimization energy management strategy [27-28]. The electrical energy consumption of the battery is transformed into an equivalent hydrogen consumption to make the two comparable. This strategy splits the power demand from the motor between the storage device and the fuel cell system in an optimal way [26].

b) BERS: When the vehicle works in the "braking regeneration" mode, the target torque is calculated based on the rotational speed, the brake pedal position and an ABS state variable [26]. With the BERS, part of the kinetic energy can be recycled, and the vehicle is kept safe during braking.

Figure 9 showed the energy flow diagram of the powertrain using ECMS and BERS [26]. There is about $6.06 \mathrm{MJ}$ was recovered from kinetic energy. The analysis conducted on china city bus show that ECMS and the BERS impact on the fuel cell net efficiency and the braking energy respectively. The contributions to the hydrogen consumption reduction of the ECMS were $2.5 \%$ and the BERS and $15.3 \%$.

Pedal positions and shift signals determine the vehicle modes, which can be divided into two modes, non-brake mode (idle, drive backward, drive forward, slide) and brake regeneration mode [29].

3. The AOC-EMS System

Almost similar to ECMS in previous section, the main goal is to split the FC and the auxiliary power source in FC Hybrid power source. This split is the main part of the Energy Management Strategy (EMS). An Adaptive Optimal-Control (AOC) algorithm is subsequently developed and customized for synthesizing an optimal EMS.

Previous research conducts by Wei-song et al. come in result that AOC-EMS system is able to synthesize an optimal EMS through reinforcement learning [30]. The AOC-EMS system needs an early procedure to obtain convergent portion for each neural network. In that procedure, the full pattern of driving cycle should be presented to the system so that all possibility of driving condition may come to anticipation. After the early procedure, an action network shall constitute an approximate optimal strategy of the optimal-control problem. The AOC-EMS system can also fine tune the early action network through online learning in order to adapt to a real-world environment.

In the NEDC driving cycle the total hydrogen consumption for the fuzzy-EMS was $129.9 \mathrm{~g}$ (85.1\%) and $122 \mathrm{~g}(79.9 \%)$ for the AOC-EMS [30]. Figure 10 shows the comparison of hydrogen consumption rate for FC hybrid power source using AOC-EMS and other control system (fuzzy-EMS) in five different standard driving cycle.

\section{RESUlTS AND DisCUSSION}

The final flowchart for this strategy is shown in Figure 11. In general, combination between $\mathrm{FC} /$ supercapacitor hybrids has a better performance than FC/battery hybrid because supercapacitor can assist FC more effectively to meet a transient power demand. Other reason for supercapacitor superiority is that supercapacitor can be charged or discharged at high current, in which battery cannot function. Otherwise, battery has higher specific energy than supercapacitor so it has advantages during the vehicle start-up because of the startup time of the FC. Batteries have high energy density, whereas supercapacitor has higher power densities [2, 6]. The third ESS hybrid, high-speed flywheel, is never achieved the highest fuel efficiency of the three ESS. Yet the high speed flywheel had a potential to offer cost saving. These result that high speed flywheel is a promising technology for alternative ESS in further research. Figure 12 shows the comparison of the specific energy and the specific power of the three ESSs [7].

Topology 2 generally scores higher in fuel economy than Topology 1 for each comparison group. The ESS cost of the novel Topology 2 is significantly less than the ESS cost for Topology 1. This affects the lower ESS mass for topology 2 in every comparison group.

The installation of the FC and auxiliary power sources are depending on the type of the vehicle. When the vehicle is designed for long range, and then it shall use Advanced Li-Ion battery for its long lifespan and light mass. Instead, if it is designed for short range, then it may use $\mathrm{Pb}-\mathrm{A}$ or NiMH battery. Small vehicle should use less volume power source like Li-Ion battery. The location of the device shall depend on the architecture of vehicle where it can provide required space inside the body.

Presented nonlinear control in the fuel cell HPS topology effectively depress current ripple factor to be up to $3 \%$ and a voltage ripple factor to be up to $4 \%$ (or lower). This afford is proven enough to optimize the PEMFC in ripple factor, thus it helps increasing the life cycle as well.

Considering the hydrogen consumption was achieved up to $17.8 \%$ totally, ECMS and BERS are potential research subject to recover kinetic energy for FCHV. Although the energy losses in the fuel cell stack were about $50.5 \%$, including the losses in stacks and through the purge valves. The hydrogen cannot be $100 \%$ utilized in a real fuel cell system. The utilization coefficient may reach $90 \%$ normally, but it plummets to a low level in idling or low power requirement state. However, this part of energy losses could be reduced using an optimal purge-valve control strategy.

The average hydrogen consumption improvement using AOC-EMS was $23.3 \%$ compared to $18.7 \%$ of other control system (fuzzy-EMS) in five different driving cycles. Those improvements determine that AOE-EMS is needed in minimizing hydrogen consumption at HPS under various driving cycle.

\section{CONCLUSION}

A hybrid fuel cell vehicle utilizes a PEM fuel cell as the main power source and other ESSs as the auxiliary power source. The three ESSs discussed in this paper i.e. battery, supercapacitor/ultracapacitor and high-speed flywheel. The analysis conducted results that PEMFC and supercapacitor is the most effective hybridization. Nevertheless, those three ESSs still have their advantages and disadvantages as the research investigating hybrid ESSs with large capacity, fast charging/discharging, long lifetime, and low cost still continually conduct. 
Previous research stated that FC/battery-diodeultracapacitor topology (using inserted diode and switch) is analytically superior to $\mathrm{FC} /$ battery/Ultracapacitor topology in term of efficiency, cost and mass. The lighter the mass, the farther is the range of the vehicle in accordance of extra structural mass, heavier brake, and a larger traction.

Control strategies consists three proposed method; the using of nonlinear control system, the implementation of ECMS and BERS, and an adaptive optimal control for energy management strategy. AOC-EMS gave $23.3 \%$ improvement of hydrogen consumption rate while ECMS and BERS gave $17.8 \%$ totally, and nonlinear control system effectively depresses the ripple factor of the current and the voltage.

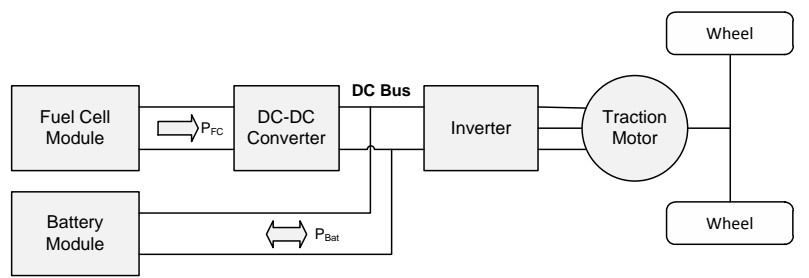

Figure 1. Structure of FC/Battery hybrid power source

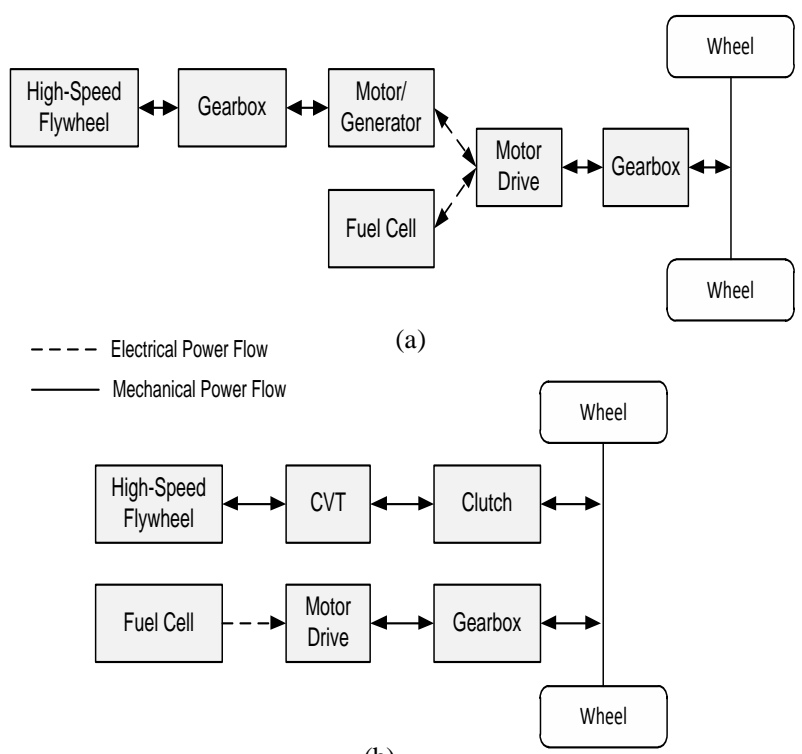

(b)

Figure 3. High speed flywheel integration with FC. (a) Electrical integration (b) Mechanical integration
Further research should be conducted to develop these strategies for more specific FCHV implementation depending on the weight of the vehicle such as for city car, van, or truck. Research based on the long range vehicle such as bus or other mass rapid transportation could emerge many new parameters.

\section{ACKNOWLEDGMENT}

The authors would like to thank Dian Andriani and Siti Fauziyah Rahman from Chonnam National University for numerous international resources on renewable energy. We also like to thank our entire colleague in Indonesian Institute of Sciences especially at Research Centre for Electrical Power and Mechatronics.

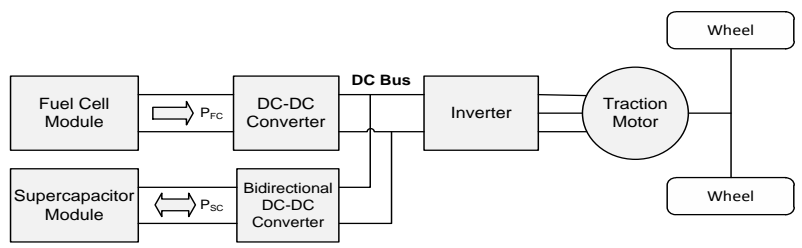

Figure 2. Structure of FC/supercapacitor hybrid power source

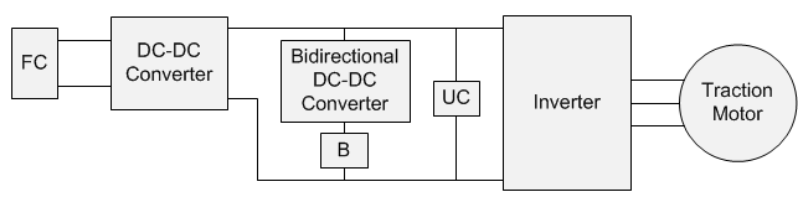

(a)

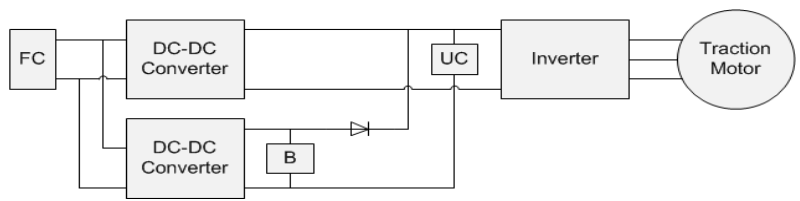

(b)

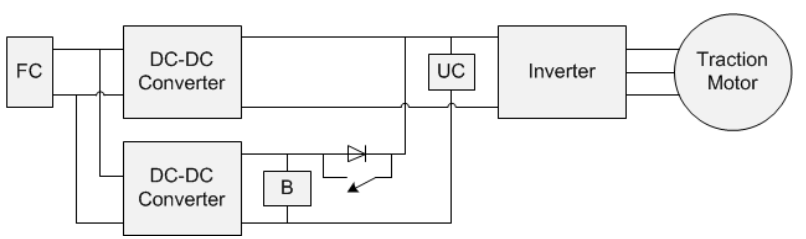

(c)

Figure 4. FC-B-UC topologies. (a) Topology 1 (b) Topology 2, Option 1 (c) Topology 2, Option 2 

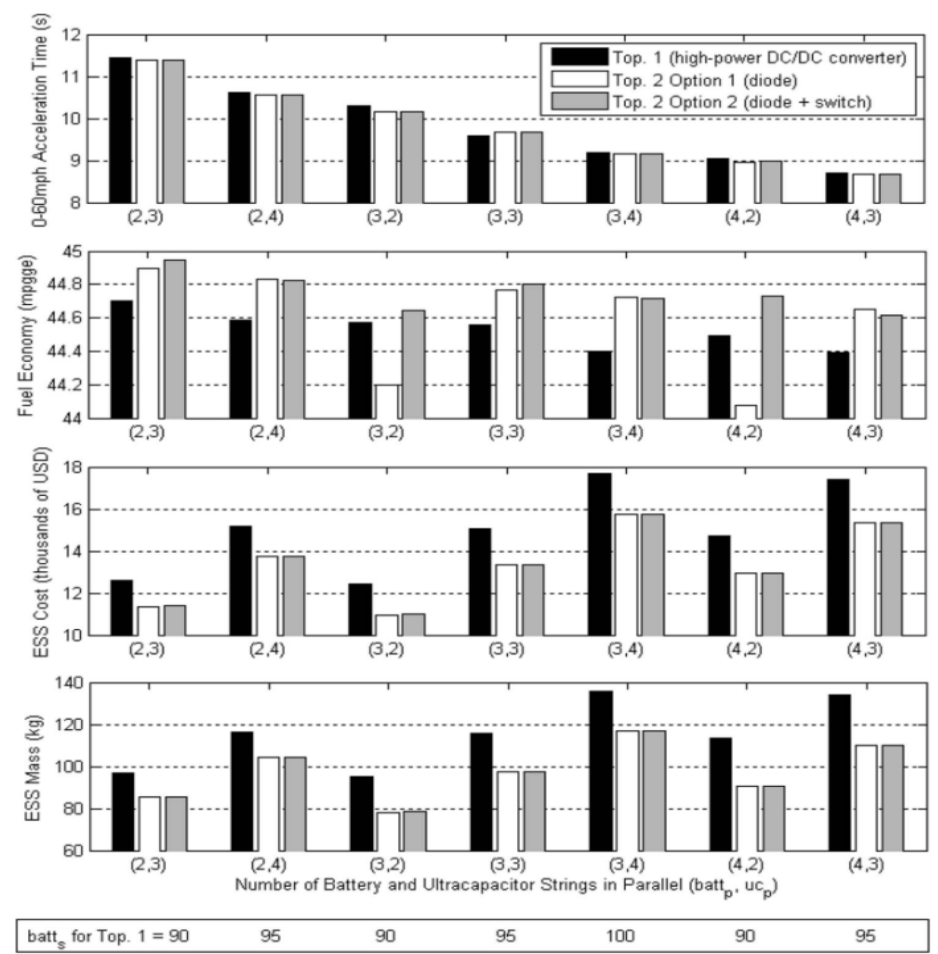

Figure 5. Parametric study results for the three FC-B-UC powertrain topologies.

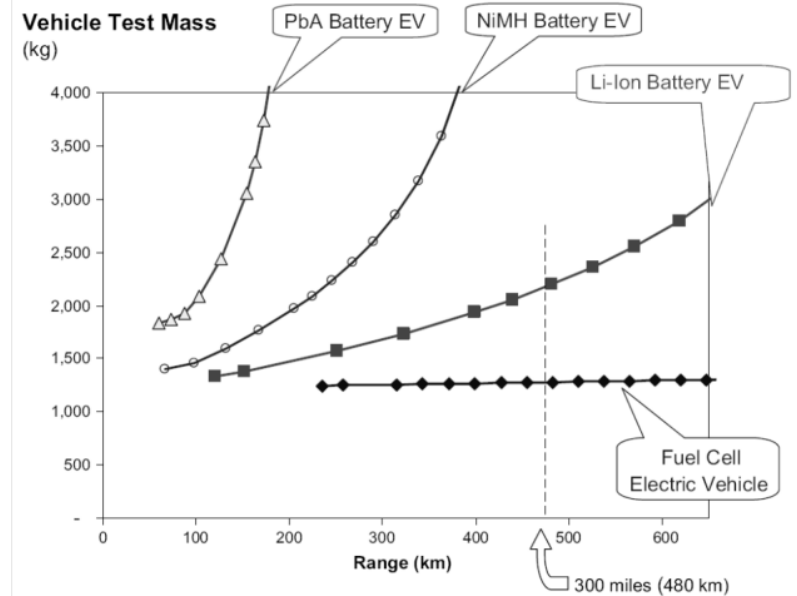

Figure 6. Calculated vehicle mass as a function of the vehicle range

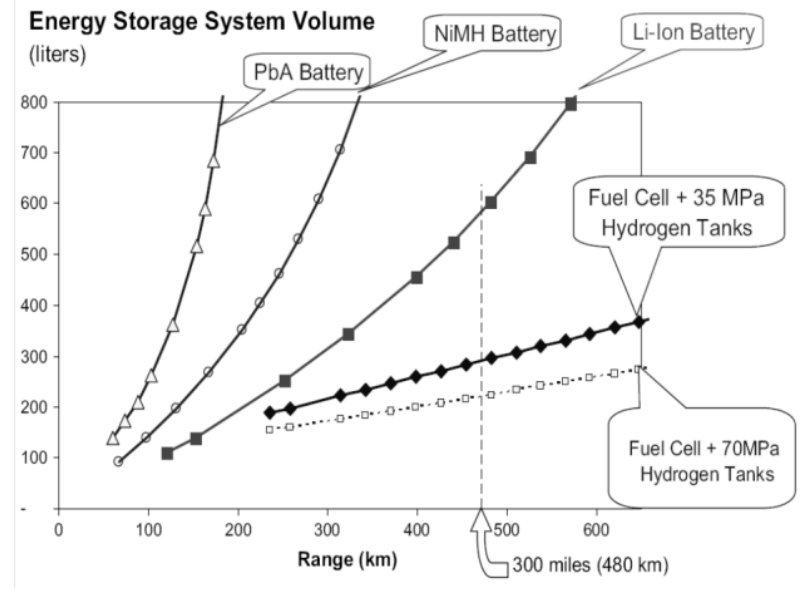

Figure 7. Calculated ESS volume as a function of vehicle range
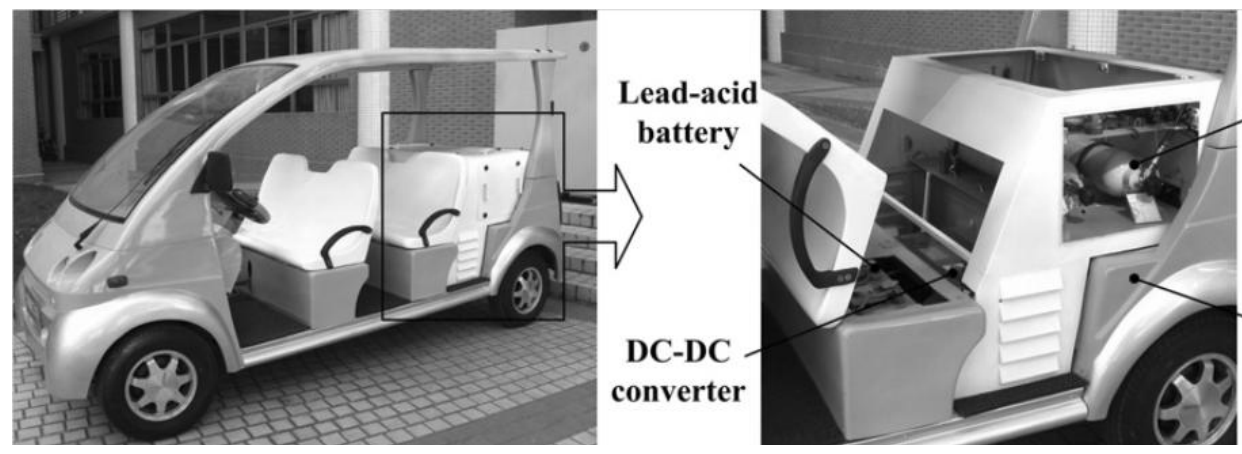

Hydrogenı

feeding

PEMFC

stack

(inside)

Figure 8. The modified electric vehicle with a PEMFC-Batteries hybrid system for light vehicle 


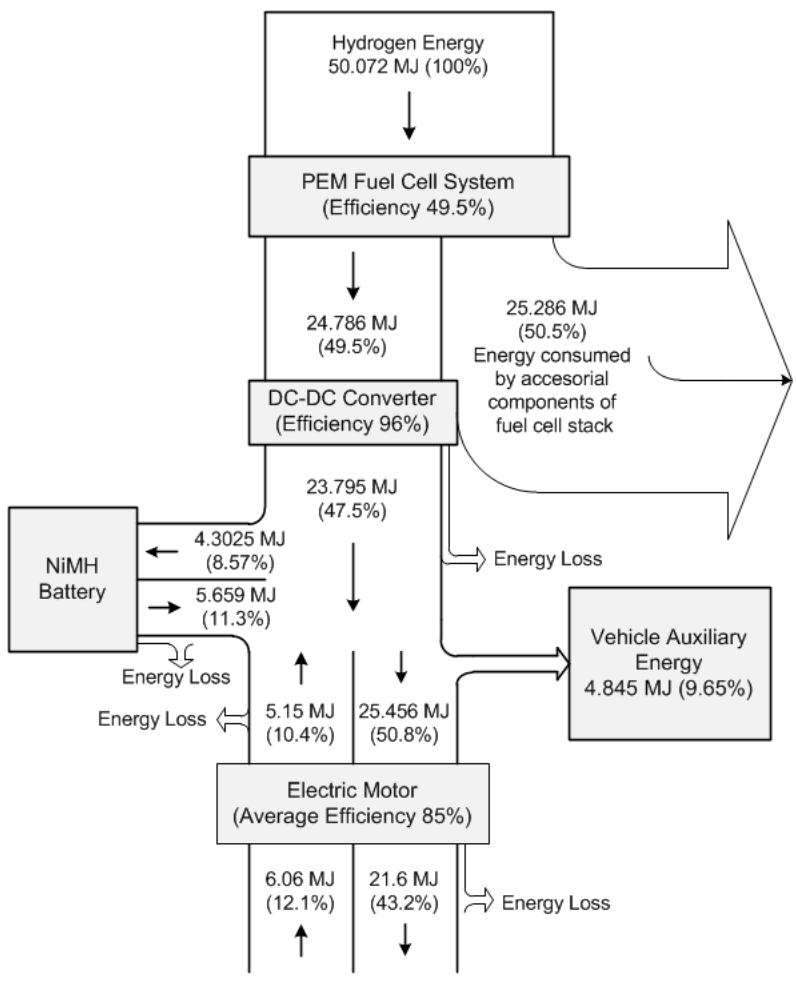

Figure 9. Energy flow diagram of the "China city bus typical cycle" with ECMS and BERS

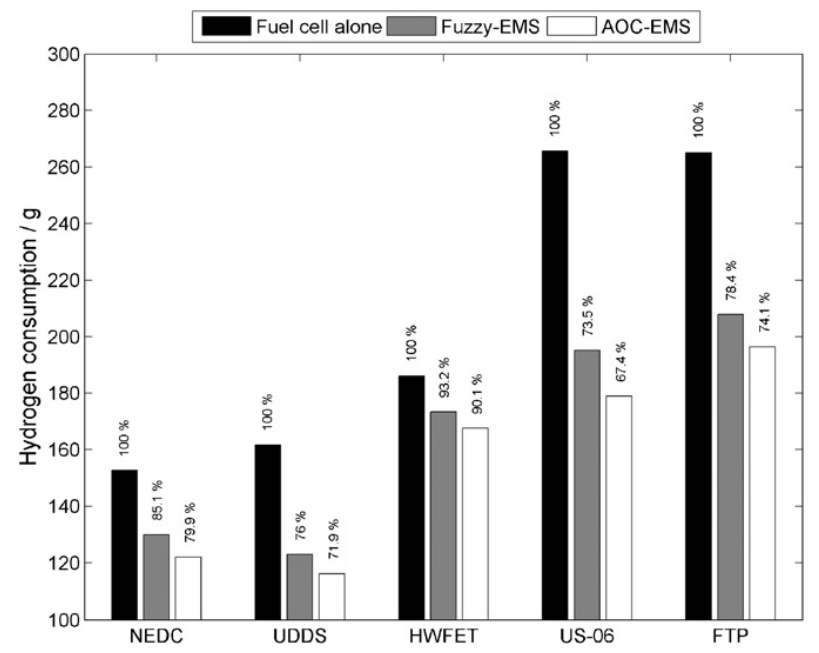

Figure 10. Hydrogen consumption rate in five standard driving cycles 


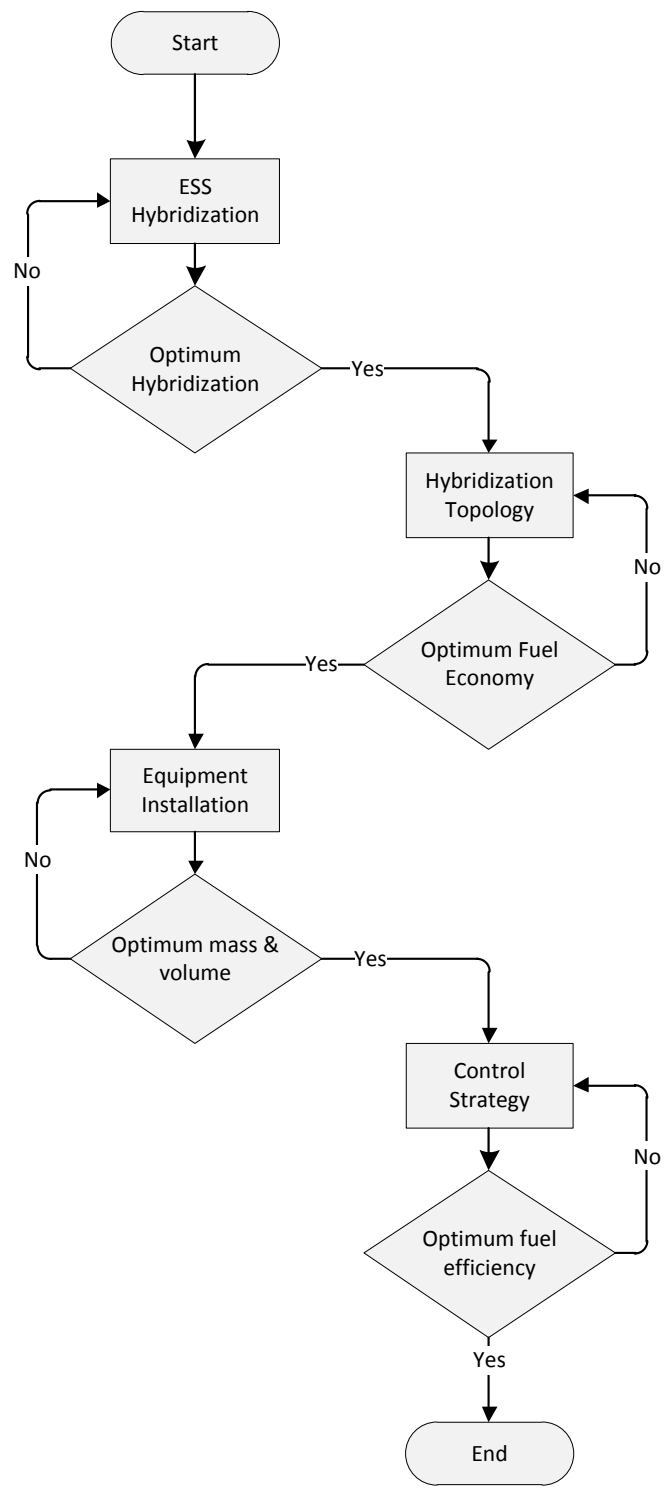

Figure 11. Flow chart of the optimization strategy

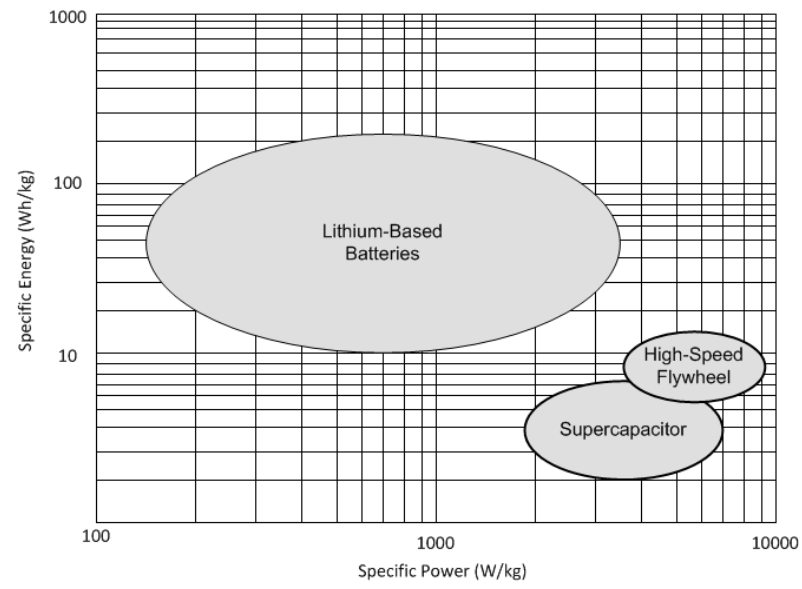

Figure 12. Comparison of battery-Ultracapacitor-High speed flywheel specific energy to specific power 


\section{REFERENCES}

[1] C. C. Chan and Y. S. Wong, "Electric vehicles charge forward," IEEE Power Energy Mag., vol. 2, no. 6, pp. 24-33, Nov./Dec. 2004.

[2] A. Khaligh and Z. Li, "Battery, Ultracapacitor, Fuel Cell, and Hybrid Energy Storage Systems for Electric, Hybrid Electric, Fuel Cell, and Plug-In Hybrid Electric Vehicles: State of the Art," IEEE Transactions on Vehicular Technology, vol. 59, no. 6, pp. 2806 - 2814 , July 2010.

[3] J. Bernard, S. Delprat, T. M. Guerra, and F. N. Buchi, "Fuel efficient power management strategy for fuel cell hybrid powertrains," Control Engineering Practice, vol. 18, pp. 408-417, 2010.

[4] C.E. Thomas, "Fuel cell and battery electric vehicles compared," international joural of hydrogen energy, vol. 34, pp. 6005-6020, 2009.

[5] N. Bizon, "A new topology of fuel cell hybrid power source for efficient operation and high reliability," Journal of Power Sources, vol. 196, pp. 3260-3270, 2011.

[6] P. Thounthong, Viboon Chunkag, Panarit Sethakul, Bernard Davat, and Melika Hinaje, "Comparative Study of Fuel Cell Vehicle Hybridization with Battery or Supercapacitor Storage Device," IEEE Transactions On Vehicular Technology, vol. 58, no. 8, pp. 3892 - 3904, Oct 2009.

[7] R. T. Doucette and M. D. McCulloch, "A comparison of highspeed flywheels, batteries, and ultracapacitors on the bases of cost and fuel economy as the energy storage system in a fuel cell based hybrid electric vehicle," Journal of Power Sources, vol. 196, pp. 1163-1170, 2011

[8] T. Kojima, T. Ishizu, T. Horiba, and M. Yoshikawa, "Development of lithium-ion battery for fuel cell hybrid electric vehicle application," Journal of Power Sources, vol. 189 , pp. 859-863, 2009

[9] J. Bernarda, M. Hofer, U. Hannesen, A. Toth, A. Tsukada, F. N. Büchi, and P. Dietrich, "Fuel cell/battery passive hybrid power source for electric powertrains," Journal of Power Sources, vol. 196 , pp. 5867-5872, 2011.

[10] S. Lukic, J. Cao, R. C. Bansal, F. Rodriguez, and A. Emadi, "Energy Storage Systems for Automotive Applications," IEEE Transactions on Industrial Electronics, vol. 55, no. 6, pp. 2258 2267 , June 2008

[11] M. Kamali-Nejad, T. Azib, G. Remy, O. Bethoux, and C. Marchand, "Optimization of a power electronic structure for hybrid Fuel Cell Ultracapacitors vehicle," in Vehicle Power and Propulsion Conference (VPPC), Lille, 1-3 Sept. 2010 , pp. 1-6.

[12] Y. Wu and H. Gao, "Optimization of Fuel Cell and Supercapacitor for Fuel-Cell Electric Vehicles," IEEE Transaction on Vehicular Technology, vol. 55, no. 6, pp. 1748-1755, Nov. 2006.

[13] A. Sripakagorna and N. Limwuthigraijirat, "Experimental assessment of fuel cell/supercapacitor hybrid system for scooters," internatioal journal of hydrogen energy, vol. 34, pp. $6036-60$ 4 4, 2009.

[14] P.F. Ribeiro, B.K. Johnson, M.L. Crow, A. Arsoy, Y. Liu., "Energy storage systems for advanced power applications," in Proceedings of The IEEE, Vol. 89, No. 12, Dec. 2001, pp. 1744 1756.

[15] O. Erdinc and M. Uzunoglu, "Recent trends in PEM fuel cellpowered hybrid systems: Investigation of application areas, design architectures and energy management approaches," Renewable and Sustainable Energy Reviews, vol. 14, pp. 2874-2884, 2010.
[16] J. Bauman and M. Kazerani, "An Analytical Optimization Method for Improved Fuel Cell-Battery-Ultracapacitor Powertrain," IEEE Transactions on Vehicular Technology, vol. 58, no. 7, pp. 3186 3197, September 2009.

[17] J. Bauman and M. Kazerani, "A comparative study of fuel cellbattery, fuel cell-ultracapacitor, and fuel cell-batteryultracapacitor vehicles," IEEE Transaction on Vehicular Technology, vol. 57, no. 2, pp. 760-769, Mar 2008.

[18] J. Bauman and M. Kazerani, "An improved powertrain topology for fuel cell-battery-ultracapacitor vehicles," in IEEE International Symposium on Industrial Electronics (ISIE) 2008 Cambridge, U.K., Jun 30-Jul 3, 2008, pp. 1483-1488.

[19] L. Gao, R. A. Dougal, and S. Liu, "Power enhancement of an actively controlled battery/ultracapacitor hybrid," IEEE Transaction on Power Electronics, vol. 20, no. 1, pp. 236-243, jan 2005.

[20] P. Thounthonga, S. Raël, and B. Davat, "Energy management of fuel cell/battery/supercapacitor hybrid power source for vehicle applications," Journal of Power Sources, vol. 193, pp. 376-385, 2009.

[21] W. Schmittinger and A. Vahidi, "A review of the main parameters influencing long-term performance and durability of PEM fuel cells," Journal of Power Sources, vol. 180 , pp. 1-14, 2008.

[22] C.E. Thomas, "Fuel cell and battery electric vehicles compared," international journal of hydrogen energy, vol. 34, pp. 6005-6020, 2009

[23] Y. Tang, W. Yuan, M. Pan, and Z. Wan, "Experimental investigation on the dynamic performance of a hybrid PEM fuel cell/battery system for lightweight electric vehicle application," Applied Energy, vol. 88, pp. 68-76, 2011

[24] N. Bizon, "Nonlinear control of fuel cell hybrid power sources: Part I - Voltage control," Applied Energy, vol. 88, pp. 2559-2573, 2011.

[25] N. Bizon, "Nonlinear control of fuel cell hybrid power sources: Part II - Current control," Applied Energy, vol. 88 , pp. 25742591, 2011.

[26] Liangfei Xu, Jianqiu Li, Jianfeng Hua, Xiangjun Li, and Minggao Ouyang, "Optimal vehicle control strategy of a fuel cell/battery hybrid city bus," international journal of hydrogen energy, vol. 34, pp. 7323-7333, 2009

[27] G. Paganelli, S. Delprat, T. M. Guerra, J. Rimaux, J. J. Santin, "Equivalent consumption minimization strategy for parallel hybrid powertrains," in Vehicular Technology Conference, 2002. VTC Spring 2002. IEEE 55th , 2002, pp. 2076 - 2081 vol.4.

[28] G. Paganelli, M. Tateno, A. Brahma, G. Rizzoni, and Y Guezennec, "Control development for a hybrid electric sportutility vehicle: strategy, implementation and field test results," in American Control Conference, Arlington, VA, USA , 2001, pp. 5064 - 5069 vol.6.

[29] X. Liang-fei, H. Jian-feng, L. Xiang-jun, M. Qing-ran, L. Jian-qiu, and O. Ming-gao, "Control strategy optimization of a hybrid fuel cell vehicle with braking energy regeneration," in IEEE Vehicle Power and Propulsion Conference (VPPC), Harbin, China September 3-5, 2008, pp. 1-6.

[30] W.-S. Lin and C.-H. Zheng, "Energy management of a fue cell/ultracapacitor hybrid power system using an adaptive optimal-control method," Journal of Power Sources, vol. 196, pp. $3280-3289,2011$. 